Jelena RAKIĆ, MA*

Pravni fakultet,

Internacionalni univerzitet

Novi Pazar
Pregledni naučni rad

UDK: 343.359.2(497.11)

336.225.68(497.11)

Primljeno:15.3.2020.

Prihvaćeno:25.6.2020.

https://doi.org/10.47152/rkkp.58.1.2.7

\title{
KRIVIČNO DELO PORESKA UTAJA - ZAKONITI I NEZAKONITI PRIHODI
}

\begin{abstract}
Zakonit osnov sticanja prihoda ili predmeta koji su od značaja za određivanje visine poreske obaveze dugo je bio jedan od neophodnih uslova za postojanje poreske utaje. Međutim, izmenjeno biće krivičnog dela više ne zahteva zakonitost prihoda ili predmeta iz čega proizilazi da poreska utaja može postojati i kada su u pitanju nezakoniti prihodi ili predmeti ukoliko su ostvareni i ostali elementi ovog krivičnog dela. Navedenu izmenu prati pitanje koje se odnosi na uspostavljanje obaveze prijavljivanja nezakonitih prihoda i predmeta poreskim organima kao i pitanje u vezi sa naplatom poreza, odnosno o mogućem uspostavljanju obaveze na plaćanje poreza i kada su prihodi ili predmeti stečeni na nezakonit način. Novelom predmetnog krivičnog dela nije uspostavljena obaveza prijavljivanja nezakonitih prihoda što proizilazi iz prava na odbranu. Ipak, to ne znači da ne može biti uspostavljena obaveza plaćanja poreza na tako stečene prihode ili predmete. Naime, nezakoniti prihodi ili predmeti obuhvaćeni su bićem poreske utaje i u onim slučajevima kada je otkriveno lice koje prihode, odnosno predmete stiče protivpravno podnosi se krivična prijava. U krivičnom postupku može se podneti imovinskopravni zahtev kojim se od okrivljenog traži da uplati iznos neplaćenog poreza čija se visina uspostavlja rešenjem Poreske uprave.
\end{abstract}

Ključne reči: porezi, poreske obaveze, poreska krivična dela, poreska utaja, zakoniti prihodi, nezakoniti prihodi.

e-mail: jelenarakic808@yahoo.com 


\section{Uvod}

Izbegavanje plaćanja poreza nije konstrukt savremenog sveta i života u njemu, već pratilac ljudskog društva od perioda kada je država uvela ovaj namet. Obaveza plaćanja poreza, globalno posmatrano, postojala je još u starim civilizacijama $^{1}$ i inkorporirana je u sve savremene pravne sisteme. Na našem prostoru odredbe o obavezi plaćanja poreza mogu se naći od perioda Dušanovog zakonika kojim je predviđeno ubiranje carskog dohotka ${ }^{2}$, a zatim u svim potonjim zakonskim propisima koji uređuju ovu oblast.

Plaćanje poreza nalazi svoj ratio u potrebi države da obezedi sredstva za pravilno funkcionisanje koje je od značaja za sve građane. Stoga je obaveza plaćanja poreza i drugih dažbina propisana Ustavom Republike Srbije. ${ }^{3}$ Međutim, nisu svi građani voljni da deo svojih prihoda ustupe državi. Razlozi za to ogledaju se u: subjektivnom osećaju poreskih obveznika da poreske dažbine utiču na smanjivanje njihove ekonomske snage i kupovne moći (Jovašević, 2005:542), finansijskim problemima s kojima se suočavaju ili, pak, sebičnosti (Hrustić, 2013:522; Risimović, 2016:3), pretpostavci da država neadekvatno usmerava materijalna sredstva dobijena od poreza (Popović, 1997:451), negativnom stavu o pravičnom rasporedu poreskog tereta između različitih poreskih obveznika (Kulić, Milošević, 2011:323) i drugo. Suočena sa otporom prilikom naplate poreza, od strane lica pod njenom jurisdikcijom, kojim se destabilizuju javne finansije, država propisuje sankcije za nedisciplinu poreskih subjekata. Ratio legis zabrane nepoželjnih ponašanja nalazi se u činjenici da se izbegavanjem poreskih obaveza direktno ugrožava osnovni fiskalni prihod države, dok indirektno utiče na sve građane s obzirom na to da se tako dobijena materijalna sredstva usmeravaju ka institucijama od opšteg interesa (škole, bolnice, sudstvo, policija itd.) s obzirom na to da poreski deficit negativno utiče na obim i kvalitet njihovih usluga (Tomaš, 2010:46).

Kršenje poreskih propisa dovodi do deliktne odgovornosti koja može predstavljati privredni prestup ili krivično delo što zavisi od težine povrede postojeće poreske obaveze.

1 Tako su trgovci u Kini za vreme dinastije Han bili opterećeni visokim porezima. U Rimu su birana dva cenzora koji su procenjivali imovinu u cilju ubiranja poreza, a od perioda vladavine Julija Cezara sakupljanje poreza nalazilo se na visokom mestu među bitni zadacima upravnog aparata (Karličić, 2015:95-96).

2 Propisano je da carski dohodak koji može biti soća, odnosno žitni danak caru, namet i harač, daje svaki čovek i to pola na Mitrovdan i pola na Božić. Davao se novčani danak i danak u žitu. Žitni danak moga se platiti i novcem (perperom) (Novaković, 1870:9-10).

3 Službeni glasnik RS, br. 98/2006, čl. 91 
Poreskim krivičnim delima nanosi se najviše štete fiskalnom sistemu jedne države. Ova krivična dela propisana su Zakonom o poreskom postupku i poreskoj administraciji (u nastavku: ZPPPA) 4 i Krivičnim zakonikom (u nastav$\mathrm{ku}: \mathrm{KZ})^{5}$. Poreska utaja predstavlja centralno poresko krivično delo predviđeno odredbama Krivičnog zakonika u glavi krivičnih dela protiv privrede.

Prema ranijem krivičnopravnom rešenju zakonitost prihoda predstavljala je conditio sine qua non za postojanje poreske utaje. Zakonodavac više ne propisuje zakonitost prihoda kao jedan od ključnih uslova za postojanje poreske utaje, na koji način izlazi iz okvira tradicionalnog poimanja ovog krivičnog dela. Novo zakonsko rešenje dovelo je do nedoumica u vezi sa tim da li su nezakoniti prihodi obuhvaćeni poreskom utajom, ali i uspostavljanjem obaveze na prijavljivanje nezakonitih prihoda ili predmeta i obaveze plaćanja poreza u odnosu na ovako stečene prihode ili predmete. Shodno navedenom cilj rada je dobijanje odgovore na postavljena pitanja.

\section{Krivično delo poreska utaja}

Poresku utaju karakteriše blanketna dispozicija te je za dokazivanje potrebno konsultovanje drugih propisa koji ne pripadaju oblasti krivičnog prava $^{6}$, što ukazuje na kompleksnu strukturu ovog krivičnog dela.

Poreska utaja vrši se u nameri da se potpuno ili delimično izbegne plaćanje poreza, doprinosa ili drugih propisanih dažbina i to davanjem lažnih podataka o stečenim prihodima, predmetima ili drugim činjenicama koje su od uticaja na utvrđivanje poreske obaveze ili neprijavljivanjem istih, kada postoji obaveza prijavljivanja ili prikrivanjem podataka koji se odnose na utvrđivanje poreske obaveze, pri čemu visina izbegnute poreske obaveze prelazi iznos od milion dinara (KZ, čl. 225, st. 1).

Objekt zaštite kod poreske utaje je fiskalni sistem kao glavni nosilac ekonomskog sistema svake države. Kao objekt napada mogu se naći porezi, doprinosi ili druge dažbine koje su svrstane u javni prihod.

4 Službeni glasnik RS, br. 80/2002, 84/2002 - ispr., 23/2003 - ispr., 70/2003, 55/2004, 61/2005, $85 / 2005$ - dr. zakon, 62/2006 - dr. zakon, 63/2006 - ispr., dr. zakona, 61/2007, 20/2009, 72/2009 - dr. zakon, 53/2010, 101/2011, 2/2012 - ispr., 93/2012, 47/2013, 108/2013, 68/2014, 105/2014, $91 / 2015$ - autentično tumačenje, 112/2015, 15/2016, 108/2016, 30/201895/2018 i 86/2019

5 Službeni glasnik RS br. 85/2005, 88/2005 ispr., 107/2005 - ispr., 72/2009, 111/2009, 121/2012, 104/2013, 108/2014, 94/2016 i 35/2019

$6 \mathrm{~S}$ tim u vezi ZPPPA propisuje relevantne činjenice koje se odnose na postupak utvrđivanja, naplate i kontrole javnih prihoda, zatim prava i obaveza poreskih obveznika, registracija poreskih obveznika (čl. 1). Drugi propisi su od značaja za utvrđivanje da li je određeno lice u konkretnom slučaju izvršilo ovo krivično delo, rečju drugi propisi upotpunjuju blanketnu dispoziciju poreske utaje (Mrvić Petrović, 2018:120; Radulović, 2010:466). 
Formulacijom „ko u nameri da potpuno ili delimično izbegne plaćanje poreza, doprinosa ili drugih propisanih dažbina daje lažne podatke o stečenim prihodima, predmetima ili drugim činjenicama..." zakonodavac je propisao da učinilac ovog krivičnog dela može biti poreski obveznik ukoliko preduzme neku od predviđenih radnji izvršenja. Obaveza na ispunjenje neke radnje određene poreskopravnim odnosom propisana je za fizička i pravna lica (ZPPPA, čl. 12), ali se kao izvršioci poreske utaje mogu naći i njihovi zakonski zastupnici. $^{7}$

Radnju krivičnog dela zakonodavac je odredio alternativno i može biti ostvarena ukoliko se: daju lažni podaci o stečenim prihodima, predmetima ili drugim činjenicama, ne prijave stečeni prihodi onda kada postoji obaveza njihovog prijavljivanja ili se na neki drugi način prikrivaju podaci relevantni za utvrđivanje poreske obaveze. Zakonodavac nije ograničio broj i varijetete radnje izvršenja s obzirom na to da je upotrebio formulaciju „, ko na drugi način prikrije..." što listu radnji čini znatno širom budući da se njome, osim najčešćih radnji izvršenja, obuhvata i neodređeni broj radnji koje se do sada nisu pojavile u praksi, ali se mogu očekivati. Krivično delo poreska utaja može se izvršiti davanjem lažnih podataka, odnosno radnjom činjenja, ili tako što se ne prijave stečeni prihodi, predmeti ili druge činjenice koje su od bitnog značaja za određivanje poreza, doprinosa ili drugih dažbina, odnosno radnjom nečinjenja. Kada je radnja izvršenja preduzeta neprijavljivanjem poreski obveznik uopšte ne navodi činjenice koje su od značaja za utvrđivanje poreza ili propušta da u propisanom roku podnese poresku prijavu ${ }^{8}$ (Nicević, Ivanović, 2013:142). Radnja krivičnog dela može biti ostvarena i prikrivanjem relevantnih podataka na neki drugi način, dakle kako činjenjem tako i nečinjenjem (Anđelković, Jovašević, 2006:194). Primera radi ovo krivično delo postojalo bi kada preduzetnik zasnuje sa radnicima radni odnos u kom slučaju postoji obaveza poslodavca da obračuna i plati poreze i doprinose na zarade pri čemu sa radnicima dogovori mesečnu zaradu višu od propisane najniže zarade, ali u poslovnoj dokumentaciji evidentira da se radnicima isplaćuje najniža zarada (Milošević, Bošković, 2009:262; Nicević, Ivanović, 2013:145). U tom slučaju postoji razlika između stvarne zarade radnika i zarade prema kojoj se obračunava poreska osnovica jer je poreska osnovica niža u odnosu na onu koja bi trebalo da bude uzimajući u obzir faktičko stanje. Ovo krivično delo postojaće i u slučaju kada recimo obveznik poreza

7 Zakonski zastupnici fizičkog lica mogu biti roditelji maloletnog lica, staralac poslovno nesposobnog lica i dr.; zakonski zastupnik pravnih lica je fizičko lice koje je kao takvo upisano u propisani registar. Osim toga, poreske obaveze lica koje zastupaju ispunjavaju i poslovođa preduzetnika i privremeni staralac zaostavštine (ZPPPA, čl. 15).

8 Pojam, sadržina poreske prijave, način i rok podnošenja kao i mogućnost njene izmene određeni su ZPPPA čl. 38-40. 
na imovinu daje lažne podatke o broju članova domaćinstva, korisne površine zgrade i stanova, srodnosti naslednika i dr. (Milošević, Bošković, 2009:269). U ovom slučaju učinilac u poresku prijavu unosi lažne podatke o bitnim činjenicama za utvrđivanje poreske obaveze s ciljem da umanji visinu iste. Osim navedenih zabeleženi su drugi pojavni oblici poreske utaje kao što su: davanje lažnih podataka o broju zaposlenih lica ili broju članova domaćinstva ili broju dece koja se školuju, o radnom statusu bračnog partnera (Anđelković, Jovašević, 2006:195; Radulović, 2010:467); propuštanje poreskog dužnika da se prijavi poreskim vlastima (Jovašević, 2017:124); neprijavljivanje prihoda poreskom organu ili prijavljivanje nižih prihoda od ostvarenih, prijavljivanje odbitaka po osnovu rashoda koji su lažni ili su bili manji od navedenog iznosa ili isticanje odbitaka čija svrha nije istinita (Popović, 2012:624); nepravilno obračunavanje poreskih obaveza, lažno bilansiranje pojedinih pozicija, vođenje dvojnog knjigovođstva (Nicević, Ivanović, 2013:143) i drugo. S obzirom na to da poreski obveznik dovodi u zabludu merodavni organ $\mathrm{u}$ vezi sa činjenicama koje su od bitnog značaja za pravilno određivanje visine poreske obaveze u teoriji je zastupljeno mišljenje da poreska utaja predstavlja poseban modalitet prevare (Lazarević, 2006:625). Postoje i mišljenja da je poreska utaja lakša od krivičnog dela prevare (Stojanović, Perić, 2006:197).

Za postojanje krivičnog dela neophodno je da iznos utajenog poreza čije se plaćanje izbegava prelazi milion dinara. Ukoliko je iznos niži od minimalno propisanog neće postojati krivično delo poreska utaja već poreski prekršaj. Reč je o objektivnom uslovu inkriminacije koji se vezuje za jednu kalendarsku godinu (Kulić, Milošević, 2011:328).

U pogledu subjektivnog elementa bića krivičnog dela potrebno je da postoji umišljaj koji je određen ispunjenjem dodatnog uslova - postojanjem namere, odnosno potreban je direktni umišljaj kao najviši stepen svesti i volje učinioca da jednom od alternativno predviđenih radnji izvršenja potpuno ili delimično izbegne plaćanje poreske obaveze. Namera predstavlja posebno subjektivno obeležje krivičnog dela, odnosno psihički fenomen koji utiče na preduzimanje određenih delatnosti radi postizanja određenog cilja. Ukoliko kod učinioca nije postojala namera da delimično ili u potpunosti izbegne plaćanje poreza, doprinosa ili drugih dažbina onda ne možemo govoriti o ispunjenosti subjektivnog elementa poreske utaje a samim tim neće postojati ovo krivično delo (Škulić, Delibašić, 2018:71).

Krivično delo poreska utaja ima dva kvalifikovana oblika. Da li će postojati osnovni ili neki od kvalifikovanih oblika zavisi od visine iznosa čije se plaćanje izbegava. Ukoliko učinilac izbegava plaćanje najmanje pet miliona dinara radiće se o prvom težem obliku, dok se najteži oblik ovog krivičnog dela vezuje za minimalni novčani iznos od petnaest miliona dinara (KZ, čl. 225, st. 2 i 3). Da bi postojao jedan od dva kvalifikovana oblika 
poreske utaje zakonodavac zahteva da kod učinioca postoji umišljaj, odnosno svest i htenje izbegavanja obaveze u većem iznosu, ali ne mora postojati svest o tačnom iznosu.

Delo je dovršeno preduzimanjem radnje izvršenja pri čemu nije od značaja da li je učinilac uspeo u nameri da u potpunosti ili delimično izbegne plaćanje poreza ili druge propisane obaveze, ali je od značaja da visina obaveze čije se plaćanje izbegava prelazi milion dinara.

Zakonom je propisana kazna zatvora uz koju se uvek kumulativno izriče i novčana kazna. Za osnovni oblik dela zaprećeno je kaznom od jedne do pet godina. Kazna zatvora za prvi kvalifikovani oblik može se izreći u rasponu od dve do osam godina, dok je za najteži oblik propisana kazna zatvora od tri do deset godina ( KZ, čl. 225, st. 2 i 3).

\subsection{Poreska utaja-zakoniti i/ili nezakoniti prihodi}

Prema ranijem normativnom rešenju svojstvo stečenih prihoda bilo je od krucijalnog značaja za postojanje poreske utaje. Izostavljanje termina „,zakoniti“ iz zakonskog opisa ovog krivičnog dela aktuelizuje pitanje u vezi sa postojanjem poreske utaje kada se radi o nezakonitim prihodima.

Mišljenje da su nezakoniti prihodi obuhvaćeni poreskom utajom postojalo je i pre izmene bića ovog krivičnog dela. Tako pojedini autori smatraju da su nezakoniti prihodi bili obuhvaćeni formulacijom „ko na drugi način prikrije podatke koji se odnose na utvrđivanje poreske obaveze“ (Hrustić, 2013:524). Prema mišljenju drugih autora krivično delo poreska utaja moglo je postojati kada se radnja izvršenja odnosila na prihode koji potiču od obavljanja delatnosti koja nije zabranjena, ali za koju obveznik nema odobrenje (Kulić, Milošević, 2011:327-328) što proizilazi iz odredbi Zakona o porezu na dohodak građana ${ }^{9}$ kojim je propisano da se prihodom od samostalne delatnosti smatra i prihod ostvaren trajnim ili sezonskim iskorišćavanjem zemljišta u nepoljoprivredne svrhe (vađenje peska, šljunka i kamenja, proizvodnja kreča, cigle, crepa, ćumura i sl.), inkubatorskom proizvodnjom živine i drugim sličnim delatnostima, nezavisno od toga da li su kao samostalne delatnosti registrovane kod nadležnog organa.

9 Službeni glasnik RS, br. 24/2001, 80/2002, 80/2002 - dr. zakon, 135/2004, 62/2006, 65/2006 ispr., 31/2009, 44/2009, 18/2010, 50/2011, 91/2011 - odluka US, 7/2012 - usklađeni din. izn., 93/2012, 114/2012 - odluka US, 8/2013 - usklađeni din. izn., 47/2013, 48/2013 - ispr., 108/2013, 6/2014 - usklađeni din. izn., 57/2014, 68/2014 - dr. zakon, 5/2015 - usklađeni din. izn., 112/2015, 5/2016 - usklađeni din. izn., 7/2017 - usklađeni din. izn., 113/2017 i 7/2018 - usklađeni din. izn., čl. 31 , st. 2. 
Sa stanovišta teorije nezakoniti prihodi mogli su biti obuhvaćeni poreskom utajom, ali je zakonodavac ovo krivično delo vezivao za zakonito stečene prihode tako da se u onim slučajevima kada su prihodi bili stečeni recimo prodajom robe na crno, odnosno kada nisu bili zakoniti nije moglo govoriti o poreskoj utaji već o nekom drugom krivičnom delu. ${ }^{10} \mathrm{U}$ vezi sa pomenutim je i presuda Apelacionog suda u Nišu, Kžl. br. 431/10 u kojoj se navodi „Ako je prihod bio zakonit a nisu plaćeni odgovarajući porezi, onda se može raditi o krivičnom delu poreske utaje, a ako prihod nije bio zakonit onda se može raditi o nekom drugom krivičnom delu, u kom slučaju se taj prihod ne može oporezivati već se mora oduzeti“. Isti stav nalazimo i u presudi Opštinskog suda u Paraćinu K. br. 280/07 od 23.06.2008. godine i presudi Apelacionog suda u Kragujevcu Kžl.br.2666/10 od 07.09.2010. godine „Kako odredba čl. 229, st. $1 \mathrm{KZ}$ glasi: ,ko u nameri da potpuno ili delimično izbegne plaćanje poreza, doprinosa ili drugih dažbina, daje lažne podatke o zakonito stečnim prihodima, o predmetima ili drugim činjenicama koje su od utcaja za utvrđivanje ovakvih obaveza, ili ko u istoj nameri u slučaju obavezne prijave ne prijavi zakonito stečeni prihod itd.“, što upućuje na to da je radnja izvršenja vezana za zakonito stečene prihode, a ne i za one koji su stečeni na protivpravan način, time što je u izreku presude prvostepeni sud uneo utvrđenje da je okrivljeni nabavljenu robu i prodavao na „crno“, što znači na nedozvoljen i protivpravan način, i takve radnje kvalifikovao kao krivično delo iz člana $229 \mathrm{KZ}$ učinio je izreku presude nerazumljivom i protivurečnoj samoj sebi.“ Presudom Apelacionog suda u Beogradu, Kž1. 4/2011 od 10.6.2011. godine zauzet je sledeći stav „Krivično delo poreska utaja ne postoji kada se radnja izvršenja dela ne vezuje za zakonito stečene prihode. Naime,da bi postojalo krivično delo poreska utaja, neophodno je da je roba pribavljena na legalan način, pa da ovlašćeno lice u svojoj poslovnoj dokumentaciji umanji visinu poreza ili na drugi način prikaže neistinite podatke o porezu, a što nije slučaj u konkretnoj situaciji, jer su okrivljeni slali fakture koje nije pratila roba, pa se ne može govoriti o krivičnom delu poreska utaja, s obzirom da se radnja izvršenja ne vezuje za zakonito stečene prihode.“

Ipak, ukoliko se osvrnemo na skoriju sudsku praksu stiče se utisak da su sudovi prilikom donošenja odluka pristupali ekstenzivnijem shvatanju pojma ,zakoniti““. Tako je Viši sud u Kragujevcu presudom, 1K-34/17 od 24.11.2017. godine oglasio krivim direktora društva s ograničenom odgovornošću navodeći da isti „u nameri da delimično izbegne plaćanje poreza nije prijavio zakonito stečeni prihod ... na taj način što je izvršio promet

10 Na primer krivično delo građenje bez građevinske dozvole (KZ, čl. 219a); krivično delo nedozvoljena proizvodnja (čl. 234); krivično delo nedozvoljena trgovina (čl. 235); krivično delo neovlašćeno organizovanje igara na sreću (čl. 352); krivično delo neovlašćeno bavljenje određenom delatnošću, čl. $353 \mathrm{i} \mathrm{dr}$. 
robe bez evidentiranja u knjigovođstvenoj dokumentaciji tako što neplaćeni iznos od prodaje robe nije uplatio na poslovni račun privrednog društva, a izlaz robe nije opravdao verodostojnim računovodstvenim ispravama“. Presudom Osnovnog suda u Sremskoj Mitrovici, 1K 377/17 od 18.12.2017. godine, oglašen je krivim poljoprivredni proizvođač koji „...u nameri da potpuno izbegne plaćanje poreza na dodatu vrednost, nije prijavio zakonito stečeni prihod, tako što je izvršio uzgoj stoke - tovnih svinja, nerasta i krmača i njihov dalji promet - prodaju privrednom subjektu ... koji promet nije evidentirao u svojim poslovnim knjigama, za isti nije izdao PDV račune i nije obračunao i podneo poreske prijave što je bio dužan da učini prema Zakonu o porezu na dodatu vrednost i na taj način nije obračunao, nije prijavio nadležnom poreskom organu niti platio PDV... na koji način je izbegao plaćanje poreza na dodatu vrednost ...“. Presudom Višeg suda u Pirotu, K 4/2016 od 20.11.2017. godine, kada okrivljenog oglašava krivim sud navodi „...radnja izvršenja okrivljenog se ogleda u nabavci i prodaji tečnog naftnog gasa bez evidencije u poslovnim knjigama preduzeća..." . U sva tri navedena slučaja radi se o postojećim poreskim obveznicima koji svoju delatnost obavljaju u skladu sa zakonom, odnosno imaju dozvolu za bavljenje određenom delatnošću. U prvom i drugom slučaju iz sudske prakse okrivljeni su vršili prodaju robe bez evidentiranja iako su za istu imali urednu ulaznu dokumentaciju dok u trećem slučaju nije postojala uredna kako ulazna tako i izlazna dokumentacija. Prema našem mišljenju u navedenim slučajevima radilo se o prometu i/ili nabavci robe na crno što se ne može smatrati zakonitim ukoliko bi se prilikom tumačenja ovog termina zauzeo rigidan stav.

Čini se da je Vrhovni kasacioni sud dao smernicu za fleksibilnije tumačenje pojma zakonitih prihoda zauzevši stav „... kada je reč o pitanju uticaja zakonitosti načina sticanja prihoda mora se praviti razlika između prihoda stečenih zakonitom delatnošću obveznika poreza, delatnošću koja nije zabranjena ali za koju obveznik nema odobrenje i delatnošću koja predstavlja krivično delo, privredni prestup ili prekršaj“" (KZZ 112/2013 od 17.10.2013. godine). S tim u vezi uzimajući u obzir pozitivno određenje poreske utaje učiniocem bi se moglo smatrati i lice koje u skladu sa zakonom obavlja delatnost $\mathrm{i}$ bavi se recimo trgovinom na malo prehrambenim proizvodima $u$ odnosu na koje uredno izmiruje poreske obaveze, ali se terenskom kontrolom ustanovi da prodaje duvanske proizvode za koje je potreban upis u posebni registar $^{11}$ a ne poseduje takvu dozvolu što znači da duvanske proizvode

11 Zakon o duvanu, Službeni glasnik RS br. 101/2005, 90/2007, 95/2010, 36/2011, 6/2012-usklađeni izn., 69/2012- usklađeni izn., 93/2012, 8/2013-usklađeni izn., 64/2013-usklađeni izn., 108/213, 4/2014-usklađeni izn., 79/2014-usklađeni izn., 5/2015-usklađeni izn., 67/2015-usklađeni izn., 5/2016-usklađeni izn., 65/2016-usklađeni izn., 8/2017-usklađeni izn., 76/2017-usklađeni izn. i 18/2018-usklađeni izn., čl. 45 
nabavlja i prodaje na crno. Dalje, ukoliko se neki već registrovani privredni subjekt odluči na privremeni prekid obavljanja privredne delatnosti i u odnosu na svoju odluku ispoštuje zakonsku proceduru, odnosno registruje privremeni prekid obavljanja delatnosti ${ }^{12}$, ali nastavi da posluje, što znači da se u tom periodu obavljanja delatnosti nalazi u zoni sive ekonomije i da su tako ostvareni prihodi, posmatrano u užem smislu, nezakoniti mogao bi se smatrati učiniocem poreske utaje. Pored toga kao primer možemo navesti lice koje se bavi proizvodnom delatnošću i koje prodajom svojih proizvoda ostvaruje prihode ali nije registrovani preduzetnik kod Agencije za privredne registre $(\mathrm{APR})^{13}$ ili drugog organa kada je registracija potrebna radi obavljanja delatnosti , što znači da nema poreski identifikacioni broj (PIB) $)^{14}$ i kao preduzetnik nije vidljiv poreskim organima. Takva delatnost može biti recimo pružanje usluga keteringa koja se neretko reklamira putem društvenih mreža. Spremanje hrane za ketering obavlja se u stanovima, kućama i sl., u kom slučaju je upitno ispunjavanje standarda koji se tiču higijenskih, sanitarnih i drugih uslova. Ukoliko delatnost ovog ,nepostojećeg“ preduzetnika bude otkrivena moglo bi se govoriti o postojanju poreske utaje. Učiniocem poreske utaje mogao bi se smatrati i preduzetnik, bez obzira na to da li se radi o registrovanoj ili neregistrovanoj delatnosti, koji zapošljava sve ili pojedine radnike bez zaključenog ugovora o radu.

Krivičnopravna norma više ne predstavlja prepreku da nezakoniti prihodi budu obuhvaćeni poreskom utajom. To znači da se preduzimanjem navednih kao i brojnih drugih radnji može izvršiti poreska utaja ukoliko su ispunjeni ostali elementi ovog krivičnog dela, odnosno da iznos utajenog poreza prelazi milion dinara i da je kod lica postojala namera da preduzimanjem radnje izvršenja delimično ili u potpunosti izbegne poresku obavezu. U vezi sa namerom kao subjektivnim elementom bića krivičnog dela polazimo od toga da se ista utvrđuje na osnovu faktičkog ponašanja učinioca. Postojanje namere može se konstatovati ukoliko učinilac ne evidentira promet što navodi na zaključak da to čini u cilju izbegavanja poreske obaveze (Kulić, Milošević, 2011:332). Logičnim zaključivanjem namera bi postojala i kada se radi o nezakonitim prihodima ili predmetima budući da poslovanje na nezakonit

12 Zakon o privrednim društvima, Službeni glasnik RS, br. 36/2011, 99/2011, 83/2014-dr. zakon, 5/2015 i 44/2018, čl. 90

13 Postupak registracije propisan je Zakonom o postupku registracije $\mathrm{u}$ agenciji za privredne registre Službeni glasnik RS, br. 99/2011, 83/2014 i 31/2019, čl. 5-24.

14 Poreski identifikacioni broj - PIB dodeljuje se od strane Poreske uprave fizičkim licima, preduzetnicima i pravnim licima u cilju da budu identifikovani kao poreski obveznici što proizilazi iz odredbi ZPPPA. Postupak i način dodeljivanja PIB-a propisan je članom 2 Pravilnika o poreskom identifikacionom broju, Službeni glasnik RS, br. 57/2003, 68/2003, 32/2009, 48/2010 i 44/2018 dr. zakon 
način ima za cilj izbegavanje plaćanja poreza. Jedan od vidova utaje poreza upravo je neprijavljivanje, odnosno neregistrovanje radnje, preduzeća ili delatnosti koja se obavlja. Na taj način direktno se izbegava plaćanje poreskih obaveza vezanih za obavljanje delatnosti i posedovanje preduzeća i radnje (Jovašević, 2016:140) što se može uzeti kao indikator za postojanje namere kod učinioca.

Dakle, poreska utaja postoji i kada se obavlja delatnost za koju lice nema odobrenje kada je takvo odobrenje potrebno, odnosno kada je u pitanju neregistrovani subjekt ili kada se vrši promet robe za koju lice nema potrebno ovlašćenje uz postojanje namere i ispunjenje objektivnog uslova inkriminacije. S tim u vezi s aspekta novelirane poreske utaje pod nezakonitim prihodima ili predmetima podrazumevaju se oni koji su nastali kao rezultat obavljanja delatnosti koje nisu zabranjene zakonom. Tako ne bismo mogli govoriti o poreskoj utaji kada su prihodi ili predmeti nastali prodajom robe do koje se došlo izvršenjem krađe, ili kada su isti nastali kao rezultat neovlašćene proizvodnje i stavljanja u promet opojnih droga i sl., koje su zakonom zabranjene.

\section{Poreska obaveza i nezakoniti prihodi}

Tumačenjem sintagme „stečeni prihodi“ koju koristi zakonodavac jasno je da zakonitost prihoda više nije jedan od uslova za postojanje poreske utaje. Ipak nedoumice postoje u vezi sa uspostavljanjem obaveze na prijavljivanje nezakonito stečenih prihoda ili predmeta kao i u vezi sa naplatom poreza od tako stečenih prihoda ili predmeta.

\subsection{Uspostavljanje obaveze na prijavljivanje nezakonito stečenih prihoda}

Jedan broj autora ukazuje na to da novim zakonskim rešenjem nije uspostavljena obaveza fizičkih i pravnih lica na prijavljivanje nezakonito stečenih prihoda u odnosu na koje bi se odredila visina poreske obaveze (Lazarević, Škulić, 2015:56; Škulić, Delibašić, 2018:74; Risimović, 2016:14). Naime, zastupnici ovog stava navode da bi pomenuta obaveza u tom slučaju značila da zakonodavac zahteva samoprijavljivanje učinilaca krivičnih dela (Lazarević, Škulić, 2016:56; Škulić, Delibašić, 2018:74). U literaturi se mogu naći mišljenja da kada lice koje je otkriveno u vršenju krivičnog dela ili prekršaja kao i neovlašćenom obavljanju privredne delatnosti bude pozvano da podnese prijavu o tako ostvarenim nezakonitim prihodima nema obavezu da se odazove 
poreskim organima i podnese poresku prijavu sa istinitim podacima jer bi na taj način optužilo samo sebe (Miloš navedeno prema Jovašević, 2016:99). Saglasni smo sa navedenim mišljenjima budući da bi obaveza prijavljivanja nezakonito stečenih prihoda bila u suprotnosti s pravom na odbranu o čemu je i sudska praksa zauzela jasan stav. Prema opšteusvojenom stavu lica koja su stekla prihode ne nelegalan, protivzakonit način (npr. obavljanja samostalne delatnosti od strane lica koje nema odobrenje od strane nadležnog organa, rad na „crno“, delatnosti u oblasti sive ekonomije) nemaju obavezu da takve prihode prijave jer bi u tom slučaju sebe prijavila kao izvršioca nekog krivičnog dela što zakon ne traži s obzirom na to da je pravom na odbranu obuhvaćeno da učinilac krivičnog dela ima pravo da prikriva ili na drugi način izbegava utvrđivanje svoje odgovornosti za izvršeno krivično delo ( Presude Vrhovnog suda Srbije Kž. I 1384/73 i Kž. I 196/83).

\subsection{Obaveza plaćanja poreza u odnosu na nezakonito stečene prihode}

Lice koje je prihode steklo nezakonito nema obavezu da tako stečene prihode prijavi poreskim organima što ne znači da tako stečeni prihodi ne mogu biti oporezovani, odnosno da se ne može utvrditi visina poreske obaveze $\mathrm{i}$ ista naplatiti.

Ulteraturi dominira mišljenje da senemožeoporezivati onoštoje stečeno nezakonito i protivpravno (Kulić, Milošević, 2011:327; Popović, 2012:627; Radulović, 2010:468; Risimović, 2016:12; Škulić, Delibašić, 2018:74), jer bi to značilo odobravanje nezakonitog osnova sticanja takvih prihoda (Kulić, Milošević, 2011:327). Ipak, mogu se sresti i suprotna mišljenja kojima se ukazuje na dve kategorije nezakonitih prihoda. Prvoj grupi pripadaju prihodi od dopuštene delatnosti čije je obavljanje uslovljeno postojanjem odobrenja od nadležnog organa. U drugu grupu svrstavaju se prihodi ostvareni vršenjem krivičnih dela. Razlike između ovih grupa, koje se ogledaju u ugrožavanju i povredi zaštićenih dobara, prava i interesa, opravdavaju oporezivanje prihoda koji pripadaju prvoj grupi, odnosno onih koji su ostvareni na osnovu obavljanja dopuštene delatnosti za koju je potrebno odobrenje, ali kada takvo odobrenje nije izdato (Vuković, 2009:160). Sledi da bi mogla biti uspostavljena obaveza plaćanja poreza u odnosu na nezakonite prihode.

Kao što je već obrazloženo u radu nezakoniti prihodi obuhvaćeni su bićem poreske utaje. Odredbama ZPPPA propisano je da se pod poreskim krivičnim delima podrazumeva preduzimanje radnji u cilju potpunog ili delimičnog izbegavanje plaćanja poreza, kada se sačinjava ili podnosi falsifikovana dokumentacija koja je od značaja za oporezivanje, ugrožavanje 
naplate poreza i poreske kontrole, kada se radi o nedozvoljenom prometu akciznih proizvoda ili su preduzete druge nazakonite radnje koje su u vezi sa izbegavanjem i pomaganjem u izbegavanju plaćanja (čl. 135, st. 2). Osim toga ZPPPA propisuje da se javnom tužiocu podnosi krivična prijava kada postoje osnovi sumnje da su prihodi ili predmeti proistekli iz poreskog krivičnog dela (čl. 137, st. 1). S obzirom na to da je navedenom definicijom o poreskim krivičnim delima obuhvaćena poreska utaja Poreska policija podnosi krivičnu prijavu kada tokom obavljanja delatnosti iz svoje nadležnosti otkrije lice u odnosu na koje postoje osnovi sumnje da je učinilo ovo krivično delo. Posmatrano iz krivičnopravnog ugla određivanje visine poreske obaveze u direktnoj je vezi s vođenjem krivičnog postupka. Naime, utvrđivanje tačnog iznosa poreske obaveze koja se izbegava proizilazi iz činjenice da je isti od važnosti za rešavanje pitanja postojanja krivičnog dela kao i meritornog odlučivanja budući da ovaj iznos predstavlja objektivni uslov inkriminacije. U vezi s navedenim postoji mišljenje da sud nije vezan rešenjem poreskog organa koje se odnosi na visinu poreske obaveze koja se izbegava jer je jedino krivični sud ovlašćen da ceni da li je izvršeno krivično delo, odnosno da prilikom odlučivnja o optuženju nije neophodno da se iznos obaveze čije se plaćanje izbegava prethodno utvrđuje u poreskom postupku od strane poreskog organa (Kulić, Milošević, 2011:328). S navedenim mišljenjem možemo se delimično saglasiti. Saglasni smo s navodima da je jedino sud ovlašćen da ceni da li je izvršeno krivično delo s obzirom na to da je teret dokazivanja optužbe na tužiocu ${ }^{15}$. Ipak, ne možemo se saglasiti sa stavom da nije neophodno u poreskom postupku utvrditi iznos poreske obaveze čije se plaćanje izbegava. Naime, dužnost suda nije da utvrđuje tačan iznos poreza, odnosno poreske obaveze koja se izbegava već to spada u delatnost Poreske uprave donošenjem poreskog rešenja (ZPPPA, čl. 54, st. 1). I u onim slučajevima kada poreski organi identifikuju obavljanje neregistrovane, odnosno neprijavljene delatnosti ZPPPA propisuje da se donosi rešenje kojim će se utvrditi visina poreske obaveze (čl. 129a, st. 2). Dakle, obaveza plaćanja poreza u odnosu na zakonito i nezakonito stečene prihode i predmete uspostavlja se rešenjem Poreske uprave. Prema stavu sudske prakse iznos neplaćenog poreza može biti predmet imovinskopravnog zahteva kojim se traži da okrivljeni uplati državi iznos neplaćenog poreza (Presuda Apelacionog suda u Kragujevcu Kž. 1533/2012 od 20. aprila 2012 navedeno prema Rsimović, 2016:10), što se u skladu sa izmenjenim bićem krivičnog dela odnosi kako na zakonite tako i na nezakonite prihode.

15 Zakonik o krivičnom postupku, Službeni glasnik RS, br. 72/2011, 101/2011, 121/2012, 32/2013, 45/2013, 55/2014 i 35/2019 čl. 15 , st. 2 


\section{Zaključak}

Prema pozitivnopravnom određenju poreska utaja se vrši u nameri potpunog ili delimičnog izbegavanja plaćanja poreza, doprinosa ili drugih propisanih dažbina $\mathrm{i}$ to davanjem lažnih podataka o stečenim prihodima, predmetima ili drugim činjenicama koje su od uticaja na utvrđivanje poreske obaveze ili neprijavljivanjem istih kada postoji obaveza prijavljivanja ili prikrivanjem podataka koji se odnose na utvrđivanje poreske obaveze bez obzira na to da li se radi o zakonito ili nezakonito stečenim prihodima ili predmetima.

Ovakvim propisivanjem poreske utaje zakonodavac zauzima stav netolerancije u odnosu na poreski (ne)moral. To je učinio brisanjem nejasno definisane granice prilikom tumačenja pojmova zakonitih i nezakonitih prihoda ili predmeta. Intencija zakonodavca svakako nije bila ozakonjenje prihoda koji potiču od vršenja krivičnih dela tako da se ne može govoriti o poreskoj utaji ukoliko je prihod stečen delatnostima koje su zabranjene zakonom. Dakle, pod nezakonitim prihodima ili predmetima podrazumevaju se oni prihodi ili predmeti stečeni obavljanjem zakonom dozvoljenih delatnosti nezavisno od toga da li postoji ili ne postoji odobrenje za obavljanje određene delatnosti i da li se radi o registrovanom ili neregistrovanom subjektu. S tim u vezi u onim slučajevima kada je otkriveno lice koje obavlja zakonom dozvoljenu delatnost u cilju delimičnog ili potpunog izbegavanja poreske obaveze može se govoriti o poreskoj utaji ukoliko su ispunjeni ostali elementi ovog krivičnog dela.

Kada govorimo o poreskim obavezama neophodno je praviti razliku između obaveze na prijavljivanje nezakonitih prihoda - koja ne postoji i potencijalne obaveze plaćanja poreza u odnosu na tako stečene prihode. Naime, činjenica da neko lice nema obavezu da prijavi prihode ili predmete koji su stečeni na nezakonit način nije garancija da poreski dug neće biti naplaćen. U slučaju nezakonitih prihoda nepostojanje obaveze na prijavljivanje takvih prihoda poreskim organima ne anulira dužnost obavljanja delatnosti u zakonom predviđenim okvirima. Ovo dalje znači da s obzirom na to da svojstvo prihoda nije od značaja za postojanje krivičnog dela poreska utaja onda nezakoniti prihodi mogu biti predmet imovinskopravnog zahteva. Poreska obaveza može se naplatiti u odnosu na nezakonite prihode, odnosno u svakom konkretnom slučaju uspostavlja se obaveza plaćanja poreza bez obzira na to da li su prihodi zakoniti ili nezakoniti donošenjem rešenja od strane Poreske uprave. 


\section{Literatura}

- Anđelković, M., Jovašević, D. (2006) Izbegavanje plaćanja poreza: fiskalni i krivičnopravni aspekt. Niš: Centar za publikacije Pravnog fakulteta.

- Hrustić, H. (2013) Poreska krivična dela. Glasnik advokatske komore Vojvodine, 10, str. 521-539.

- Jovašević, D. (2017) Poreska utaja kao oblik ispoljavanja privrednih krivičnih dela U: I. Stevanović, V. Čolović (ur.) Privredna krivična dela, Beograd: Institut za kriminološka i sociološka istraživanja, Institut za uporedno pravo, str. 119-131.

- Jovašević, D. (2016) Poreska krivična dela, Beograd: Institut za kriminološka i sociološka istraživanja.

- Jovašević, D. (2005) Poreska evazija i poreska krivična dela oblici ispoljavanja poreske evazije. Bezbednost, 4, str. 541-564.

- Karličić, M. (2015) Osvrt na krivično delo poreska utaja. Tužilačka reč, 28, str. 95-107.

- Krivični zakonik, Službeni glasnik RS, br. 85/2005, 88/2005 - ispr., 107/2005 ispr., 72/2009, 111/2009, 121/2012, 104/2013, 108/2014, 94/2016 i 35/2019

- Kulić, M., Milošević, G. (2011) Odnos krivičnih dela poreske utaje i neuplaćivanja poreza po odbitku u srpskom krivičnom pravu. Anali Pravnog fakulteta u Beogradu, 2, str. 321-343.

- Lazarević, J., Škulić, M. (2015) Osnovne planirane novele Krivičnog zakonika Srbije. Bilten Vrhovnog kasacionog suda, 2, str. 32-75.

- Lazarević, Lj. (2006) Komentar Krivičnog zakonika Republike Srbije. Beograd: Savremena administracija

- Milošević, G., Bošković, G. (2009) Poreska evazija u Republici Srbiji. Bezbednost, 1-2, str. 254-275.

- Mrvić Petrović, N. (2018) Značaj naknadnog izvršenja poreske obaveze na kažnjavanje za poreske kaznene delikte U: J. Kostić, A. Stevanović (ur.) Finansijski kriminalitet, Beograd: Institut za uporedno pravo, Institut za kriminološka i sociološka istraživanja, str. 119-129.

- Nicević, M., Ivanović R.A. (2013) Poreska utaja. Ekonomski izazovi, 3, str. 139150

- Popović, D. (1997) Nauka o porezima i poresko pravo. Budimpešta, Beograd: Institut Otvoreno društvo/Institut za ustavnu i zakonodavnu politiku, Savremena administracija

- Popović, I. (2012) Poreska utaja u našem pravu U: P. Dimitrijević (ur.) Zaštita ljudskih i manjinskih prava u evropskom prostoru, Niš: Pravni fakultet, str. 619636. 
- Radulović, Lj. (2010) Krivično delo poreske utaje iz člana 229 KZ RS (akcenti iz sudske prakse). Pravo i privreda, 4-6, str. 463-475.

- Pravilnik o poreskom identifikacionom broju, Službeni glasnik RS, br. 57/2003, 68/2003, 32/2009, 48/2010 i 44/2018 - dr. zakon

- Risimović, R. (2016) Radnja izvršenja krivičnog dela poreska utaja. NBP- Žurnal za kriminalistiku i pravo, 3(1), str. 1-19.

- Stojanović, Z., Perić, O. (2006) Krivično pravo-posebni deo. Beograd: Pravna knjiga

- Škulić, M., Delibašić, V. (2018) Poreska utaja - normativna konstrukcija i neka sporna pitanja U: M. N. Simović (ur.) Krivično zakoodavstvo i funkcionisanje pravne države, Trebinje: Srpsko udruženje za krivičnopravnu teoriju i praksu, Grad Trebinje, Ministartsvo pravde Republike Srpske

- Tomaš, R. (2010) Siva ekonomija u Bosni i Hercegovini. Sarajevo: Friedrich-Ebert-Stiftung.

- Ustav Republike Srbije, Službeni glasnik RS, br. 98/2006

- Vuković, M. (2009) Poreska utaja u policijskoj i sudskoj praksi. Beograd: Službeni glasnik.

- Zakon o duvanu, Službeni glasnik RS br. 101/2005, 90/2007, 95/2010, 36/2011, 6/2012-usklađeni izn., 69/2012- usklađeni izn., 93/2012, 8/2013-usklađeni izn., 64/2013-usklađeni izn., 108/213, 4/2014-usklađeni izn., 79/2014-usklađeni izn., 5/2015-usklađeni izn., 67/2015-usklađeni izn., 5/2016-usklađeni izn., 65/2016-usklađeni izn., 8/2017-usklađeni izn., 76/2017-usklađeni izn. i 18/2018-usklađeni izn.

- Zakonik o krivičnom postupku , Službeni glasnik RS, br. 72/2011, 101/2011, 121/2012, 32/2013, 45/2013, 55/2014 i 35/2019

- Zakon o porezu na dohodak građana, Službeni glasnik RS, br. 24/2001, 80/2002, 80/2002 - dr. zakon, 135/2004, 62/2006, 65/2006 - ispr., 31/2009, 44/2009, 18/2010, 50/2011, 91/2011 - odluka US, 7/2012 - usklađeni din. izn., 93/2012, 114/2012 - odluka US, 8/2013 - usklađeni din. izn., 47/2013, 48/2013 - ispr., 108/2013, 6/2014 - usklađeni din. izn., 57/2014, 68/2014 - dr. zakon, 5/2015 usklađeni din. izn., 112/2015, 5/2016 - usklađeni din. izn., 7/2017 - usklađeni din. izn., 113/2017 i 7/2018 - usklađeni din. izn.

- Zakon o poreskom postupku i porekoj administraciji, Službeni glasnik RS, br. $80 / 2002,84 / 2002$ - ispr., 23/2003 - ispr., 70/2003, 55/2004, 61/2005, 85/2005 - dr. zakon, 62/2006 - dr. zakon, 63/2006 - ispr., dr. zakona, 61/2007, 20/2009, 72/2009 - dr. zakon, 53/2010, 101/2011, 2/2012 - ispr., 93/2012, 47/2013, 108/2013, 68/2014, 105/2014, 91/2015 - autentično tumačenje, 112/2015, $15 / 2016,108 / 2016,30 / 2018,95 / 2018$ i 86/2019 
- Zakon o privrednim društvima, Službeni glasnik RS, br. 36/2011, 99/2011, 83/2014- dr. zakon, 5/2015 i 44/2018

- Zakon o postupku registracije u agenciji za privredne registre, Službeni glasnik RS, br. 99/2011, 83/2014 i 31/2019

- Zakonik Stefana Dušana cara srpskog 1349-1354 (1870) U: Stojan Novaković (ur.), Beograd. Dostupno na: http://www.uzzpro.gov.rs/doc/biblioteka/digitalna-biblioteka/Zakonik\%20Stefana\%20Dusana\%20cara\%20srpskog\%20 1349.\%20i\%201354.pdf, posećen 10.10.2019

\section{Jelena RAKIĆ, MA}

Faculty of Law, International university of Novi Pazar

\section{TAX EVASION - LEGAL AND ILLEGAL REVENUES}

The legal basis of obtaining revenue or any object relevant for determining tax evasion liability has been one of the necessary conditions for tax evasion for a long time. However, changed substance of a criminal offence no longer demands the legality of revenue, nor objects, which implicates that the notion of tax evasion may occur in the cases of illegal revenue as well, on account of other elements of this criminal offence being fulfilled. It further implies the question of illegal revenue accounts and objects due to be passed to tax authorities, as well as the question related to tax payment i.e. imposing tax claim to the revenues and objects obtained illegally. The novelty in the subject of criminal offence doesn't set the obligation of illegal revenue accounts which stems from the right defence. Nevertheless, it doesn't preclude the obligation of tax payment for the revenues and objects thus obtained. Namely, illegal revenues and objects are comprised by the substance of tax evasion, and criminal charges are filed in the cases of revealing a subject who obtains the revenues and objects illegally. The criminal proceeding involves the filling of restitution claim, by means of which the charged subject is due to pay the tax debt, whose amount was previously determined by tax authorities' decision

Key words: taxes, tax obligation, tax criminal offence, tax evasion, legal revenue, illegal revenue. 